\title{
Hepatitis C Virus RNA Positive
}

National Cancer Institute

\section{Source}

National Cancer Institute. Hepatitis C Virus RNA Positive. NCI Thesaurus. Code C162042.

An indication that hepatitis C RNA has been detected in a sample. 